\title{
A MOMENT'S INADVERTENCE SHOULD NOT BRING DOWN THE HEAVENS: RETHINKING PROPORTIONALITY IN NEGLIGENCE LAW IN NEW ZEALAND
}

\author{
Karan Venter*
}

\begin{abstract}
True proportionality between the degree of a tortfeasor's fault and the extent of a plaintiff's loss is unachievable in negligence law in New Zealand. As Mallon J's judgment in Strathboss Kiwifruit Ltd $\mathrm{v}$ Attorney-General highlighted, the concept of proportionality can only be used to negate an alleged tortfeasor's duty of care, thereby eliminating the potential for liability. This approach does not accommodate differing levels of disproportionality. Moreover, relying on negligence law's liability limiting mechanisms to achieve proportionality, as Mallon J did in Strathboss, will not always be fruitful; there may still be a large gap between what a defendant has done and what the defendant is held accountable for. The extent of a tortfeasor's liability may depend on luck rather than principle. However, internationally, the wrongful conception and birth cases reveal a more nuanced use of proportionality: reducing the scope of a tortfeasor's duty of care. While this may be seen as inconsistent with negligence law's compensatory objective, I argue that a tortfeasor's interest in being free from undue burdens should constrain this objective, where necessary. This article develops on the reasoning in the wrongful conception and birth cases and borrows from the language of the Contributory Negligence Act 1947 to create a general mechanism for limiting a tortfeasor's liability in the interests of proportionality. The proposed mechanism aims to ensure that the law of negligence delivers more just results.
\end{abstract}

* Submitted for the LLB (Honours) Degree, Faculty of Law, Victoria University of Wellington, 2019. At the time of submission, the Court of Appeal had not released its judgment in Attorney-General v Strathboss Kiwifruit Ltd [2020] NZCA 98. References to the Court of Appeal's judgment have been incorporated where suitable. However, the Court of Appeal's judgment does not affect the substance of this article, which is about how to fill the lacuna in negligence law's liability limiting mechanisms that Mallon J's judgment in Strathboss Kiwifruit Ltd v Attorney-General [2018] NZHC 1559 highlighted. I am extremely grateful to my supervisor, Professor Bill Atkin, for his ongoing support and guidance. 


\section{INTRODUCTION}

In 1967, the Royal Commission of Inquiry into Compensation for Personal Injury in New Zealand recommended abolishing the negligence action for personal injuries. ${ }^{1}$ One reason for this recommendation was negligence law's tolerance for moral luck: "[r]eprehensible conduct can be followed by feather blows while a moment's inadvertence could call down the heavens." 2 This article addresses the latter scenario, through the lens of proportionality.

Proportionality is a "relational concept"; 3 it requires a reasonable balance between two actions. Moral concerns dictate the right balance. ${ }^{4}$ In criminal law, these concerns range from the belief that the use of force in self-defence should be proportionate to the threat faced, to the idea that punishment should reflect the severity of an offence. ${ }^{5}$ In the context of negligence law, proportionality should require a "reasonable relationship"6 between the degree of a tortfeasor's fault and the extent of their liability. However, Mallon J's judgment in Strathboss Kiwifruit Ltd v Attorney-General illustrates that proportionality is underdeveloped in negligence law in New Zealand. ${ }^{7}$

This article has four substantive parts. Part II discusses how Mallon J used the concept of proportionality in her duty of care analysis in Strathboss. This analysis reveals that true proportionality is unachievable in negligence law because: (a) proportionality can only be used to negate an alleged tortfeasor's duty of care; and (b) negligence law's liability limiting mechanisms do not always effectively limit a tortfeasor's liability. It also considers the Court of Appeal's brief discussion of proportionality in Attorney-General $v$ Strathboss Kiwifruit Ltd. ${ }^{8}$ Part III examines how overseas courts have used proportionality to limit doctors' liability in the wrongful conception and birth cases. It also finds that proportionality should be a constraint on negligence law's "pursuit" of compensation. ${ }^{9}$ Part IV proposes a new liability limiting mechanism in negligence law. This mechanism, which develops on the wrongful conception and birth cases and the approach of courts in assessing

1 Compensation for Personal Injury in New Zealand: Report of the Royal Commission of Inquiry (Government Printer, December 1967) at [85]. This recommendation was followed: see s 317(1) of the Accident Compensation Act 2001.

2 At [85].

3 George Letsas "Proportionality as Fittingness: The Moral Dimension of Proportionality" (2018) 71 CLP 53 at 55.

4 At 55 .

5 At 55 .

6 McFarlane v Tayside District Health Board [2002] 2 AC 59 (HL) at 106 per Lord Clyde.

7 Strathboss Kiwifruit Ltd v Attorney-General [2018] NZHC 1559 [Strathboss (HC)] at [843].

8 Attorney-General v Strathboss Kiwifruit Ltd [2020] NZCA 98 [Strathboss (CA)].

9 John CP Goldberg "Ten Half-Truths about Tort Law" (2008) 42 Val U L Rev 1221 at 1251. 
contributory negligence claims, allows courts to reduce the scope of a tortfeasor's duty of care in the interests of proportionality, thereby limiting their liability. Finally, Part V outlines the factors courts must consider in evaluating proportionality: the degree of a tortfeasor's fault and the extent of a plaintiff's recoverable loss. It will also overcome a common objection to the use of proportionality in negligence law by showing that there are degrees of negligence, both in fact and in law.

\section{STRATHBOSS KIWIFRUIT LTD V ATTORNEY-GENERAL}

In November 2010 the Psa3 bacteria, known to be harmful to kiwifruit vines, was detected in New Zealand. The bacteria rapidly spread throughout kiwifruit orchards, causing severe damage and devastating the kiwifruit industry. It was thought that the bacteria arrived on a consignment of kiwifruit pollen shipped to Kiwi Pollen's premises in Te Puke, pursuant to an import permit granted by the Ministry of Agriculture and Fisheries (MAF). ${ }^{10} \mathrm{~A}$ class of orchardists and Seeka, a post-harvest operator, sued MAF for hundreds of millions of dollars, alleging negligence under the Biosecurity Act 1993.

In a stage one decision in the High Court Mallon $\mathrm{J}$ held that MAF negligently performed its statutory functions. ${ }^{11}$ MAF made various "process errors" in granting Kiwi Pollen an import permit. ${ }^{12}$ On appeal, the Court of Appeal overturned Mallon J's decision, finding that the Crown "has a statutory immunity precluding liability for the alleged negligent acts or omissions". ${ }^{13}$ The Court went further, holding that even if the immunity question has been answered in the orchardists' favour, it would have held that the Crown did not owe the orchardists a duty of care. ${ }^{14}$ The risk of indeterminate liability was an important policy factor in this finding. ${ }^{15}$ The Court of Appeal's discussion of proportionality, comprising three paragraphs, ${ }^{16}$ does not affect the substance of this article, which is about how to fill the lacuna in negligence law's liability limiting mechanisms that Mallon J's judgment highlighted.

Returning to the High Court judgment, it is necessary to set out how Mallon J approached the duty of care question in order to see how her Honour used the concept of proportionality. Mallon J employed the fluid North Shore City Council v Attorney-General (The Grange) methodology in holding that MAF owed the orchardists (with property rights in vines) a duty to take reasonable skill

10 Now the Ministry for Primary Industries (MPI).

11 Strathboss (HC), above n 7, at [843].

12 At [33] and [13]-[19].

13 Strathboss (CA), above n 8, at [6].

14 At [7(a)] and [7(c)].

15 At [260].

16 At [261]-[263]. 
and care in its actions before the Psa 3 incursion. ${ }^{17}$ The Grange methodology divides the duty question into two stages. The first involves considering foreseeability and proximity, factors concerned "with everything bearing upon the relationship between the parties". ${ }^{18}$ Mallon J held that the loss suffered by the orchardists was foreseeable and that the relationship between the parties was sufficiently proximate. ${ }^{19}$ The second stage requires courts to evaluate whether any policy factors militate against the imposition of a duty of care; in other words, whether it is "fair, just and reasonable to impose a duty". ${ }^{20}$ Mallon J found that no policy features - including proportionality - sufficiently displaced the orchardists' compensatory interest. ${ }^{21}$

\section{A The Proportionality Analysis}

MAF argued that the alleged breaches of its duty of care were not of sufficient magnitude to mean that it was morally responsible for the loss caused by the Psa3 incursion. ${ }^{22}$ Mallon $\mathrm{J}$ rejected this argument. She began her analysis by referring to examples of disproportionality, one being a misplaced match leading to extensive loss. ${ }^{23}$ Leaving aside the aptness of this as an example of disproportionality, the message Mallon J intended to convey is unclear. She may have been observing that concerns about proportionality are commonplace or expressing the view that proportionality should not play a role in negligence law. If the latter is true, this is contrary to Invercargill City Council $v$ Southland Indoor Leisure Centre Charitable Trust ${ }^{24}$ and Minister of Education v Econicorp Holdings Ltd. ${ }^{25}$

The Court of Appeal held that the Crown's disproportionality argument was not "a significant additional factor". 26

17 Strathboss (HC), above n 7, at [13], [23] and [223]-[225]. See North Shore City Council v Attorney-General [2012] NZSC 49, [2012] 3 NZLR 341 [The Grange]; and Anns v Merton London Borough Council [1978] $\mathrm{AC} 728(\mathrm{HL})$ at 752 .

18 Strathboss (HC), above n 7, above n 11, at [224]; and Stephen Todd "Negligence: The Duty of Care" in Todd on Torts (8th ed, Thomson Reuters, Wellington, 2019) 147 at 157.

19 Strathboss (HC), above n 7, at [348] and [434].

20 At [225].

21 At [480] and [497].

22 At [471]

23 At [472].

24 Invercargill City Council v Southland Indoor Leisure Centre Charitable Trust [2017] NZCA 68, [2017] 2 NZLR 650 [Invercargill City Council (CA)].

25 Minister of Education v Econicorp Holdings Ltd [2011] NZCA 450, [2012] 1 NZLR 36.

26 Strathboss (CA), above n 8, at [261]. 


\section{Proportionality in New Zealand case law}

Courts and scholars often refer to South Pacific Manufacturing Co Ltd v New Zealand Security Consultants \& Investigations Ltd when considering proportionality. ${ }^{27}$ That case concerned whether a private investigator owed an insured party a duty of care. In the Court of Appeal, Richardson J (as he then was) held that the relationship between the plaintiff and investigator was sufficiently proximate, in part because the imposition of a duty of care would not expose the investigator to a burden "out of proportion to his moral culpability". ${ }^{28}$ However, Richardson J was not balancing the tortfeasor's fault with the financial burden of liability. Instead, he was weighing the tortfeasor's fault against the actionbased burden of liability. Essentially, his Honour was satisfied that the imposition of liability would not expose the investigator to a duty to take excessive precautions against the risk of causing loss. ${ }^{29}$ South Pacific Manufacturing has limited utility in the present context.

However, in Invercargill City Council, a majority of the Court of Appeal considered whether imposing liability would "create disproportion between the defendant's carelessness and the actual form of loss suffered by the plaintiff". ${ }^{30}$ The majority held that the Council, which allegedly had negligently issued a code compliance certificate, did not owe the Southland Leisure Centre a duty of care. ${ }^{31}$ The required proximity could not be established, in part because imposing liability would have created disproportionality between the Council's fault and the Centre's loss, which was over NZD $16,000,000 .^{32}$

Mallon J placed little weight on Invercargill City Council because the Supreme Court reversed the Court of Appeal decision, expressing, according to Mallon J, "no concern about disproportionality". ${ }^{33}$ However, a majority of the Supreme Court reduced the Council's liability by 50 per cent owing to the Centre's contributory negligence. ${ }^{34}$ It was appropriate for the Court to be unconcerned with proportionality: the Council's liability was halved, which addressed the

27 See South Pacific Manufacturing Co Ltd v New Zealand Security Consultants \& Investigations Ltd [1992] 2 NZLR 282 (CA). See for example Invercargill City Council (CA), above n 24, at n 167; and Todd "Negligence: The Duty of Care", above n 18, at 161-162.

28 Todd "Negligence: The Duty of Care", above n 18, at 307.

29 At 307.

30 Invercargill City Council (CA), above n 24, at [193] (emphasis added), as quoted in The Grange, above n 17, at [159].

31 Invercargill City Council (CA), above n 24, at [198].

32 At [194].

33 Strathboss (HC), above n 7, at [472]. See Southland Indoor Leisure Centre Charitable Trust v Invercargill City Council [2017] NZSC 190, [2018] 1 NZLR 278 [Invercargill City Council (SC)].

34 Invercargill City Council (SC), above n 33, at [114]. 
disproportionality between the Council's fault and its prima facie liability. The Court of Appeal's discussion of proportionality is still persuasive.

In Econicorp Holdings Ltd, a Court of Appeal majority quashed an order striking out the Minister of Education's claim in negligence and contract. ${ }^{35}$ Arnold $\mathrm{J}$ held that two policy features justified holding that the tortfeasor arguably owed the plaintiff a duty of care. ${ }^{36}$ One was that recognising a duty of care did not "create a liability which ... [was] disproportionate to any wrongdoing". ${ }^{37}$

More recently, in Smith v Fonterra Co-operative Group Ltd, the plaintiff sought a declaration that the defendants had unlawfully caused or contributed to greenhouse gas emissions in New Zealand. ${ }^{38}$ Wylie J, in striking out the plaintiff's negligence claim, held that "[i]f the alleged duty exists, the defendants could be subject to disproportionate liability". ${ }^{39}$ This was slightly odd, given that the plaintiff did not seek damages. ${ }^{40}$ This article does not address whether the proposed framework applies in situations where one is seeking a declaration or an injunction.

Invercargill City Council and Econicorp Holdings Ltd shows the Court of Appeal in two instances grappling with whether imposing liability on an alleged tortfeasor would strike the right balance between their fault and a plaintiff's loss. However, the Courts' approach to this issue was inflexible: proportionality could only contribute to negating a duty of care. Essentially, in New Zealand, if an alleged tortfeasor's fault is sufficiently disproportionate to a plaintiff's loss, courts may consider this in finding that either proximity is not established, or that a duty of care should not be recognised in the interests of sound policy. Under this approach, courts can only achieve proportionality in situations where an alleged tortfeasor's fault is egregiously disproportionate to a plaintiff's loss because it does not allow a tortfeasor's liability to be limited. At best, a court could use proportionality to justify holding that a duty of care was not owed to a class of individuals, therefore, limiting a tortfeasor's liability.

\section{Proportionality in overseas case law}

Internationally, courts have also tended to use proportionality in a similarly inflexible way. In Regent Holdings Pty Ltd v State of Victoria, Beach JA, in the Supreme Court of Victoria, held that the State of Victoria did not owe the plaintiff a duty of care to prevent damage caused by an "infectious herpes-like virus", in part to avoid disproportion between its fault and the plaintiff's loss, which was

35 Econicorp Holdings Ltd, above n 25.

36 At [54]-[55].

37 At [55].

38 Smith v Fonterra Co-operative Group Ltd [2020] NZHC 419.

39 At [94].

40 At [95]. 
AUD 8,200,000. ${ }^{41}$ Furthermore, in Esanda Finance Corp Ltd v Peat Marwick Hungerfords, the High Court of Australia held that auditors did not owe a duty of care to a financier who had relied on their negligent audits. ${ }^{42}$ McHugh J suggested that this avoided imposing a financial burden on the auditors out of proportion to their fault. ${ }^{43}$ Lastly, in McLoughlin v O'Brian, the House of Lords held that the plaintiff was entitled to recover damages for the psychiatric harm she had suffered due to the tortfeasor's negligence. ${ }^{44}$ However, Lord Wilberforce developed a three-stage test for determining to whom a tortfeasor owes a duty of care in cases involving psychiatric harm. ${ }^{45}$ His Lordship did so, in part, to ensure that, in future cases, any liability imposed on a tortfeasor for psychiatric harm was not disproportionate to their fault. 46

\section{Negligence law's liability limiting mechanisms}

In the High Court, Mallon J found that, in principle, negligence law's liability limiting mechanisms operate as a sieve, filtering out the potential for courts to place excessive financial burdens on tortfeasors. ${ }^{47}$ On the facts of Strathboss, her Honour held that MAF would not be liable for the complete economic consequences of the incursion because it did not owe Seeka a duty of care. ${ }^{48}$ Moreover, MAF held insurance policies that partially indemnified it from the loss claimed. ${ }^{49}$ In situations where an alleged tortfeasor is not insured, the potential for disproportionality is increased because all recoverable losses will fall directly on that tortfeasor.

If the orchardists are successful on appeal in the Supreme Court, ${ }^{50}$ it is not necessarily axiomatic that any liability imposed on MAF would be proportionate to its fault. The extent of the orchardists' recoverable loss may be disproportionate to MAF's negligence. This outcome is made more probable by the fact that the liability limiting mechanisms available to MAF - causation, remoteness, contribution and contributory negligence - cannot be used to materially limit MAF's liability. These liability limiting mechanisms will be discussed in the following paragraphs.

41 Regent Holdings Pty Ltd v State of Victoria [2013] VSC 601 at [1] and [225].

42 Esanda Finance Corp Ltd v Peat Marwick Hungerfords (1997) 188 CLR 241 at 246.

43 At 289

44 McLoughlin v O'Brian [1983] 1 AC 410 (HL).

45 At 421 .

46 At 421.

47 Strathboss (HC), above n 7, at [464]-[467], [470] and [496(a)].

48 At [262], [470], [474] and [498].

49 At [474].

50 The orchardists have "vowed" to appeal to the Supreme Court: see Eric Frykberg "Kiwifruit growers' PSA case: Government cleared of liability" (10 April 2020) Radio New Zealand <www.rnz.co.nz>. 
First, s 3(1) of the Contributory Negligence Act 1947 allows courts to reduce a tortfeasor's liability if the plaintiff, in part, contributed to the loss they incurred. ${ }^{51}$ There is no suggestion in the High Court and Court of Appeal judgments that the orchardists contributed to their losses. Secondly, New Zealand operates under a joint and several liability model concerning the liability of multiple tortfeasors. ${ }^{52}$ Each tortfeasor is liable for the whole of the plaintiff's loss. ${ }^{53}$ However, s 17(1)(c) of the Law Reform Act 1936 allows tortfeasors to seek a contribution from a tortfeasor "who is, or would if sued ... have been ... liable in respect of the same damage". ${ }^{54}$ There is no indication in the High Court and Court of Appeal judgments that any other party was responsible for the orchardists' loss.

Next, for loss to be recoverable in negligence law, a tortfeasor's breach needs to be the cause in fact, and in law, of that loss. ${ }^{55}$ Mallon J held that MAF's breach in fact caused the Psa3 incursion because it was more likely than not that the Kiwi Pollen consignment contained Psa3. ${ }^{56}$ The Court of Appeal agreed. ${ }^{57}$ If the Supreme Court overturns the Court of Appeal decision, it is likely that the case would be reverted to the High Court to determine, at a stage two hearing, whether MAF's breach in fact caused each orchardist's loss and whether MAF caused that loss in law. However, while nature assisted in spreading the bacteria, there was likely no intervening event that broke the chain of causation which would justify holding that MAF did not cause some of the loss in law.

Another liability limiting mechanism, the remoteness inquiry, which would likewise take place at a stage two hearing, empowers courts to limit a tortfeasor's liability in order to avoid rendering a tortfeasor "liable for consequences out of all proportion to the degree of wrongdoing involved". ${ }^{58} \mathrm{~A}$ tortfeasor is liable only for the kind of loss caused that a reasonable person would have foreseen occurring. ${ }^{59}$ This reasonable person is not required to foresee the extent of loss caused. ${ }^{60}$ The

51 See John G Fleming The Law of Torts (9th ed, LBC Information Services, Sydney, 1998) at 302 (this was the last edition of The Law of Torts written by John G Fleming); and Stephen Todd "Breach of Statutory Duty" in Todd on Torts (8th ed, Thomson Reuters, Wellington, 2019) 443 at 466.

52 Law Commission Review of Joint and Several Liability (NZLC IP32, 2012) at [2.1].

53 At [1.2].

54 See Stephen Todd "Multiple Tortfeasors and Contribution" in Todd on Torts (8th ed, Thomson Reuters, Wellington, 2019) 1247 at 1255-1264.

55 Stephen Todd "Causation and Remoteness of Damage" in Todd on Torts (8th ed, Thomson Reuters, Wellington, 2019) 1067 at 1068.

56 Strathboss (HC), above n 7, at [1254].

57 Strathboss (CA), above n 8, at [7(e)].

58 Todd "Causation and Remoteness of Damage", above n 55, at 1102.

59 At 1104-1105; and Overseas Tankship (UK) Ltd v Morts Dock \& Engineering Co Ltd [1961] AC 388 (PC) at 426 .

60 Todd "Causation and Remoteness of Damage", above n 55, at 1110. 
remoteness test would likely not substantially limit MAF's liability. The property damage sustained by the orchardists' vines was clearly foreseeable to a reasonable person, following from a failure to take reasonable care in granting an import permit for kiwifruit pollen. While Mallon J indicated that some of the consequential loss claimed may be too remote, ${ }^{61}$ the impact this could have on MAF's liability is unclear because the extent of the consequential loss claimed has not been determined.

Mallon J should not have negated MAF's duty of care to achieve proportionality. Indeed, holding that MAF did not owe the orchardists a duty of care would have created inverse disproportionality: MAF's fault, when weighed against the orchardists' loss, was likely not so minor as to warrant negating its duty of care. The point is that Strathboss exposes a lacuna in negligence law's liability limiting mechanisms.

\section{MECHANISMS FOR LIMITING LIABILITY}

True proportionality is currently unachievable in negligence law in New Zealand. Negligence law requires a new "retributive principle". ${ }^{62}$ Oliver Wendell Holmes Jr believed that fault justified shifting a loss to a tortfeasor. ${ }^{63}$ The degree of a tortfeasor's fault should, where necessary and practicable, determine how much of a loss shifts.

\section{A The Wrongful Conception and Birth Cases}

Internationally, a series of cases in negligence against doctors for the wrongful conception or birth of children show two potential methods for limiting a tortfeasor's liability to achieve proportionality. ${ }^{64}$ First, courts may reduce the scope of a tortfeasor's duty of care. ${ }^{65}$ Secondly, courts may declare a particular head of damages unrecoverable, in the interests of policy. ${ }^{66}$ Lord Wilberforce countenanced this latter method in Anns $v$ Merton London Borough Council when creating his two-stage formula for determining the existence of a duty of care. ${ }^{67}$

61 Strathboss (HC), above n 7, at [468].

62 Tony Honoré "The Morality of Tort Law-Questions and Answers" in David G Owen (ed) Philosophical Foundations of Tort Law (Clarendon Press, Oxford, 1995) 73 at 89.

63 Oliver Wendell Holmes Jr The Common Law (Paula J S Pereira and Diego M Beltran (eds), University of Toronto Law School, Toronto, 2011) at 86.

64 Stephen Todd "Negligence: Particular Categories of Duty" in Todd on Torts (8th ed, Thomson Reuters, Wellington, 2019) 273 at 396-397.

65 At 397

66 Craig Purshouse "Judicial reasoning and the concept of damage: Rethinking medical negligence cases" (2015) 15 Med L Int'1 155 at 160; and Rees v Darlington Memorial Hospital NHS Trust [2003] UKHL 52, [2004] 1 AC 309 at [30].

67 Anns, above n 17, at 752. Caparo Industries plc v Dickman [1990] 2 AC 605 (HL) abandoned the Anns twostage duty of care formula. 
The term "wrongful conception" captures situations where a mother conceives following a failed sterilisation operation or the provision of negligent advice. ${ }^{68}$ The phrase "wrongful birth" covers cases where a doctor wrongly informs a mother that her unborn child is healthy when the child is disabled and situations where a woman is erroneously informed that she is not pregnant. ${ }^{69}$ In these cases, parents have often claimed the costs of raising their child or lost earnings, resulting from having to leave work to care for their child. As doctors owe a duty of care in treating their patients and upbringing costs or lost earnings are a foreseeable consequence of failing to take reasonable care in sterilising or advising a patient, prima facie, these costs are recoverable. ${ }^{70}$ However, courts have generally been unwilling to award upbringing costs or lost earnings, choosing to limit doctors' liability, in part because liability for these costs is considered disproportionate to doctors' fault. ${ }^{71}$ For example, in McFarlane $v$ Tayside Health Board, a wrongful conception case, the House of Lords held that the mother could successfully claim general damages for the harm directly associated with her pregnancy and childbirth, but not for upbringing costs. ${ }^{72}$

Under the reducing the scope of a duty of care approach, a doctor's duty of care is held to cover the costs connected with pregnancy and childbirth, but to exclude upbringing costs and lost earnings. ${ }^{73}$ In McFarlane, Lord Slynn held that the doctor's duty of care did not extend to upbringing costs. ${ }^{74}$ In Rees v Darlington Memorial Hospital NHS Trust, a wrongful conception case, Lord Steyn in the House of Lords labelled the "absence of a duty of care" solution, in respect of upbringing costs, "entirely orthodox". ${ }^{75}$ In Khan $v$ MNX, a wrongful birth case, Nicola Davies LJ in the English Court of Appeal held that the scope of the doctor's duty of care did not extend to protecting the mother against all the risks associated with pregnancy and childbirth. ${ }^{76}$ On the facts, there was no "adequate link" between the scope of the doctor's duty of care and the child suffering from autism. ${ }^{77}$

Under the limited damages approach, judges have drawn a pragmatic line, demarcating damages associated with pregnancy and childbirth, which are recoverable, and damages related to a child's

68 Todd "Negligence: Particular Categories of Duty", above n 64, at 396-397.

69 At $396-397$.

70 At 396-397.

71 See for example Rees, above n 66; and McFarlane, above n 6.

72 McFarlane, above n 6.

73 Rees, above n 66, at [30].

74 McFarlane, above n 6, at 76.

75 Rees, above n 66, at [30].

76 Khan $v$ MNX [2018] EWCA Civ 2609, [2019] 4 WLR 3 at [27].

77 At [28]. 
upbringing, which is not a recoverable head of loss. ${ }^{78}$ In McFarlane, Lord Clyde held that there was no "reasonable relationship" between the doctor's fault and the plaintiff's claim for upbringing costs. ${ }^{79}$ His Lordship believed that allowing limited damages that excluded these costs provided "the proper measure of restitution". ${ }^{80}$ Lord Hope also tentatively endorsed the limited damages approach, after considering a hypothetical example of significant disproportionality where parents claim the costs of a child's private education. ${ }^{81}$

In the New Zealand context, $J v$ Accident Compensation Corporation, a wrongful conception case, involved a claim for lost earnings. ${ }^{82}$ Cooper and Asher JJ, in a joint judgment in the Court of Appeal, considered whether the plaintiff could successfully claim these earnings at common law if the statutory bar in s 317(1) of the Accident Compensation Act 2001, which prohibits claims for "damages arising directly or indirectly" out of personal injury covered by the Act, did not apply. ${ }^{83}$ Their Honours held that it was unclear whether the plaintiff would succeed in this claim, in part because the potential liability for the medical practitioner would be "disproportionate to ... the extent of the [practitioner's] negligence". 84

The wrongful conception and birth cases are controversial. ${ }^{85}$ In Parkinson v St James and Seacroft University Hospital NHS Trust, a wrongful conception case, Hale J (as she then was) in the English Court of Appeal suggested that holding a doctor responsible for the costs of raising a disabled child was not a disproportionate outcome. ${ }^{86}$ However, the rejection of the proportionality argument on the facts indicates that Hale $\mathbf{J}$ supported the use of proportionality in negligence law, when relevant. Nevertheless, in McFarlane, Lord Millett directly disapproved of considering proportionality in negligence law, arguing that concerns about disproportionality, which were "commonplace", did not justify limiting a tortfeasor's liability. ${ }^{87}$ Furthermore, in Cattanach $v$ Melchior, a wrongful conception case, a majority in the High Court of Australia held that that the parents were entitled to receive the

78 Purshouse, above n 66, at 160.

79 McFarlane, above n 6, at 106.

80 At 106

81 At 91.

$82 J v$ Accident Compensation Corporation [2017] NZCA 441, [2017] 3 NZLR 804 at [1].

83 At [38]-[39].

84 At [39]-[40].

85 Purshouse, above n 66, at 157.

86 Parkinson v St James and Seacroft University Hospital NHS Trust [2001] EWCA Civ 530, [2002] QB 266 at [95].

87 McFarlane, above n 6, at 109. 
child's upbringing costs. ${ }^{88}$ Kirby $\mathrm{J}$ commented that concerns about disproportionality between a doctor's fault and their liability were "unconvincing and unprincipled" and that the need for compensation outweighed concerns about disproportionality. ${ }^{89}$ However, I argue that the interests of tortfeasors in being free from unduly onerous burdens should balance the compensatory aim of negligence law.

\section{Balancing interests}

Scholars often argue that achieving proportionality in negligence law is inconsistent with its compensatory objective. ${ }^{90}$ "First and foremost, negligence law is a compensator." 91 Courts are required to put a plaintiff in the monetary position they would have occupied, had the negligence not occurred, through an award of compensatory damages. ${ }^{92}$ If a plaintiff is entitled to compensation reflecting their losses, this leaves no space to accommodate what a tortfeasor "deserves to pay". ${ }^{93} \mathrm{In}$ fact, through a compensatory lens, imposing liability that reflects a plaintiff's loss can never be disproportionate. ${ }^{94}$

However, negligence law also aims to prevent placing undue financial burdens on tortfeasors. ${ }^{95}$ This is particularly important when a plaintiff's losses will not be distributed among members of society because a tortfeasor is not insured. ${ }^{96}$ Courts must consider the "freedom and security" of a tortfeasor in any negligence claim. ${ }^{97}$ Tortfeasors have "a right to be free ... [from] disproportionate

88 Cattanach v Melchior [2003] HCA 38, (2003) 215 CLR 1

89 At [176]- [177]. See also Joshua Hogan "Recovery of Child-Rearing Expenses in Wrongful Conception Cases - A Comparative Analysis" (2002) 3 Hibernian LJ 41 at 56-57.

90 See for example John CP Goldberg and Benjamin C Zipursky "Tort Law and Moral Luck" (2007) 92 Cornell L Rev 1123 at $1142-1143$.

91 Allen M Linden Canadian Negligence Law (Butterworths, Toronto, 1972) at 470. See also Goldberg and Zipursky, above n 90, at 1142-1143.

92 Bill Atkin "Remedies" in Stephen Todd (ed) Todd on Torts (8th ed, Thomson Reuters, Wellington, 2019) 1273 at 1298. See also Hogan, above n 89, at 56-57; and Elizabeth Handsley "Mental Injury Occasioned by Harm to Another: A Feminist Critique" (1996) 14 Law and Inequality: A Journal of Theory and Practice 391 at 433 .

93 Goldberg and Zipursky, above n 90, at 1142-1143.

94 Mark Geistfeld "Negligence, Compensation, and the Coherence of Tort Law" (2003) 91 Geo L J 585 at 610 ; Alberta Law Reform Institute Class Actions (Final Report No 85, December 2000) at [135]; and Peter Cane Tort Law and Economic Interests (Clarendon Press, Oxford, 1991) at 473.

95 Kelly M Hnatt "Purely Economic Loss: A Standard for Recovery" (1998) 73 Iowa L Rev 1181 at 1193. See also Tame v State of New South Wales [2002] HCA 35, (2002) 211 CLR 317 at [5]; and Honoré, above n 62, at $89-90$.

96 McFarlane, above n 6, at 82 per Lord Steyn.

97 Tame v State of New South Wales, above n 95, at [5]. 
punishment". ${ }^{98}$ Currently, this principle is articulated in relation to the capacity for proportionality to negate a duty of care. This directly infringes the compensatory aim of negligence law. In this article it is proposed that the compensatory objective of negligence law operate within more nuanced "constraints set by... proportionality". 99 A plaintiff's and tortfeasor's interests should be balanced; neither should receive absolute priority over the other.

\section{Morality in the wrongful conception and birth cases}

Nevertheless, utilising the reasoning from the wrongful conception and birth cases to create a general mechanism for limiting liability to achieve proportionality is at first sight unprincipled. Issues of morality cloud the doctrinal legitimacy of these cases: when parents sue for upbringing costs, courts are forced to balance the imposition of liability against the birth of a child, which is considered a blessing. ${ }^{100}$ However, proportionality is similarly based on a view of what is morally appropriate. ${ }^{101}$ Societal attitudes, reflected in the criminal law, dictate that it is disproportionate to respond to the threat of being elbowed with murder. ${ }^{102}$ This article posits that, were societal attitudes also reflected in negligence law, liability would balance a tortfeasor's fault and a plaintiff's loss. A layperson would likely regard it as fundamentally unfair that liability in negligence law largely disregards the degree of a tortfeasor's fault. The reasoning in the wrongful conception and birth cases shares a common grounding with proportionality and can be used to formulate a broader liability limiting mechanism.

Additionally, while morality is pervasive in the wrongful conception and birth cases, the courts have still been mindful of protecting the internal coherence of negligence law. ${ }^{103}$ The logic of these cases is consistent with the theoretical underpinnings, reflected in the internal dynamics, of negligence law. The elements of negligence law centre on limiting tortfeasor liability; ${ }^{104}$ the courts achieve this in the wrongful conception and birth cases.

\section{A NEW MECHANISM FOR LIMITING LIABILITY}

This article proposes a nuanced mechanism for limiting a tortfeasor's liability to achieve proportionality. The mechanism develops on the reasoning in the wrongful conception and birth cases,

98 Robert J Rhee "A Principled Solution for Negligent Infliction of Emotional Distress Claims" (2004) 36 Ariz St LJ 805 at 869.

99 Goldberg, above n 9, at 1251.

100 See for example McFarlane, above n 6, at 110 per Lord Millett; and Todd "Negligence: Particular Categories of Duty", above n 64, at 398 .

101 Letsas, above n 3, at 55

102 At 55 .

103 McFarlane, above n 6, at 108 per Lord Millett.

104 Guido Calabresi and Alvin K Klevorick "Four Tests for Liability in Torts" (1985) 14 J Legal Stud 585. 
the approach courts take to assessing claims of contributory negligence in New Zealand and the Australian system of proportional liability concerning the liability of multiple tortfeasors.

\section{A Reducing the Scope of a Tortfeasor's Duty of Care}

The differences between limiting a plaintiff's entitlement to damages and reducing the scope of a tortfeasor's duty of care are "technical". ${ }^{105}$ The same outcome is reached, regardless of the approach adopted. ${ }^{106}$ Therefore, it is possible to insert the proposed framework into either mechanism. However, in this article it is recommended that courts should be able to limit a tortfeasor's liability for damages by reducing the scope of their duty of care.

There are three reasons for this recommendation. First, the duty inquiry is the "paramount" device used in negligence law to control the liability of an alleged tortfeasor: a defendant must owe a plaintiff a duty of care in order to be liable for negligence. ${ }^{107}$ Therefore, it is apt for courts to address the extent of a tortfeasor's liability in the duty inquiry. Secondly, courts currently consider proportionality in the duty of care analysis. As there is no justification for differing from this position, it should not be changed. Lastly, both stages of The Grange framework are capable of hosting proportionality disputes. Proportionality, in the context of negligence law, involves a claim that a tortfeasor's fault does not justify the imposition of liability for all of a plaintiff's loss. The proximity inquiry, which "enables the balancing of the moral claims of both parties", ${ }^{108}$ is the appropriate forum to address this claim. In Strathboss, Mallon J considered proportionality in the policy inquiry, which involves considering "judicial conceptions of desirable policy". ${ }^{109}$ The Court of Appeal did likewise. ${ }^{110}$ This was not inappropriate, as proportionality broadly aims to achieve "fundamental fairness" in society by ensuring that losses are evenly shared. ${ }^{111}$ However, ultimately, assessing what is fair, in the context of proportionality, requires recourse to the direct relationship between a tortfeasor's fault and a plaintiff's loss. Proportionality is best addressed in the proximity stage.

\section{Demarcating loss}

The mechanisms used by the courts in the wrongful conception and birth cases to limit doctors' liability require the existence of two distinguishable heads of loss. In these cases, it is factually coherent to separate loss associated with pregnancy and childbirth from upbringing costs or lost

105 Rees, above n 66, at [106] per Lord Millett.

106 At [30] per Lord Steyn.

107 Fleming, above n 51, at 150.

108 Fleming v Securities Commission [1995] 2 NZLR 514 (CA) at 532.

109 Todd "Negligence: The Duty of Care", above n 18, at 160.

110 Strathboss (CA), above n 8, at [242].

111 Rhee, above n 98, at 869. 
earnings. The two heads of loss, while resulting from the same negligent advice or procedure, are distinguishable in kind: one relates to physical discomfort and the other is an economic loss. Moreover, the heads of loss are distinguishable in time, as upbringing costs follow childbirth. However, in situations where the predominant head of loss claimed is singular in kind and time, it is not factually practicable to demarcate this loss into discrete categories. If a Rolls Royce is negligently damaged, the property damage sustained is indistinguishable; it is all damage to the car. Therefore, the wrongful conception and birth mechanisms cannot be used to limit the liability of a tortfeasor who causes a singular kind of loss. MAF's potential liability for property damage, as it cannot be coherently factually demarcated, could not be limited under this approach.

Nevertheless, the consequential loss claimed by the orchardists, being financial in its nature, could be factually demarcated from the property damage. However, demarcating the consequential loss claimed, and holding that it is not recoverable in the interests of proportionality, would not be conceptually coherent. There would be no conceptual justification for excluding the orchardists' claim for consequential loss because "there has never been any objection to recovery for economic loss that is consequential upon some physical harm". ${ }^{112}$ Furthermore, MAF's potential direct liability for consequential loss is not why MAF's liability may be disproportionate. Instead, the consequential loss, combined with the extensive property damage sustained by kiwifruit vines, contributes to potential liability which could, in sum, be disproportionate to MAF's fault. In contrast, preventing parents from recovering upbringing costs or lost earnings in the wrongful conception and birth cases can generally be conceptually justified on the basis that awarding this loss would be directly disproportionate to a doctor's fault. There is no "reasonable relationship" between a doctor's fault and liability for upbringing costs or lost earnings. ${ }^{113}$ The wrongful conception and birth cases are unique; ordinarily, the availability of a particular head of loss will not be why a tortfeasor's liability is disproportionate to their fault.

\section{Levels of disproportionality}

Rees and ACB $v$ Thomson Medical Pte Ltd indicate that the limited damages approach, and therefore reducing the scope of a tortfeasor's duty of care, may still be too inflexible to create true proportionality between a doctor's fault and parents' loss. In Rees, Lord Nicholls found that imposing liability for upbringing costs was disproportionate to the doctor's fault. ${ }^{114}$ His Lordship excluded liability for these costs, appearing to favour the limited damages approach. ${ }^{115}$ However, Lord Nicholls

112 Todd "Negligence: The Duty of Care", above n 18, at 253.

113 McFarlane, above n 6, at 106 per Lord Clyde.

114 Rees, above n 66, at [16].

115 At [18]. 
and the majority added a "gloss" to McFarlane, ${ }^{116}$ ordering that GBP 15,000 be paid, in addition to the pregnancy and childbirth costs, to recognise the wrong done. ${ }^{117}$ This suggests that an additional monetary award was necessary to achieve exact proportionality. Moreover, in $A C B$, the Singapore Court of Appeal, while denying a claim for upbringing costs by utilising the limited damages approach, held that the plaintiff had suffered a loss of genetic affinity and assessed the quantum of this loss at 30 per cent of the child's upbringing costs. ${ }^{118}$ This award was thought to be proportionate to the tortfeasor's fault. ${ }^{119}$

Rees and $A C B$ illustrate that the wrongful birth and conception mechanisms do not accommodate for situations where there are differing levels of disproportionality. Directly using these cases to create a broad mechanism for limiting liability would draw arbitrary distinctions. If a tortfeasor's liability was considered disproportionate, the extent to which their liability could be reduced would depend on the categorisation of the plaintiff's loss. And, the categorisation process would not promote consideration of the degree of the tortfeasor's fault. For example, suppose that two tortfeasors, in different cases, through their negligence cause a significant level of property damage and consequential loss. The first tortfeasor causes the harm through "a moment's inadvertence", ${ }^{120}$ which meets the breach threshold, and the second, through more moderate negligence. The liability of both could only be reduced to the same extent, despite the second tortfeasor's conduct exhibiting a higher degree of fault. The liability imposed on both tortfeasors would be more proportionate to their fault, but it would not accurately reflect their degree of fault. The process of demarcating heads of loss is unable to accommodate different levels of fault, and therefore, differing levels of disproportionality.

\section{B Reducing Liability by a Percentage}

A more nuanced approach to reducing the scope of a tortfeasor's duty of care is needed. The Contributory Negligence Act, and the Australian system of proportional liability in relation to multiple tortfeasors, ${ }^{121}$ provide a solution. They essentially permit courts to allocate a percentage of blameworthiness to a tortfeasor, excluding liability for any loss not attributable to this fault. In Invercargill City Council, a majority in the Supreme Court fixed the Centre's contributory negligence at 50 per cent, which accordingly corresponded with a reduction in the Council's liability by 50 per

116 Todd "Negligence: Particular Categories of Duty", above n 64, at 399.

117 Rees, above n 66, at [19].

118 ACB v Thomson Medical Pte Ltd [2017] SGCA 20, [2017] 4 LRC 187 at [139].

119 At [150].

120 Compensation for Personal Injury in New Zealand, above n 1, at [85].

121 See for example Owen Hayford "Proportionate liability - its impact on contractual risk allocation" (2010) 26 BCL 11. 
cent. ${ }^{122}$ This reinforces the view that negligence law is concerned with "fundamental fairness"; ${ }^{123}$ it is not fair for a tortfeasor with minor fault to be liable for extensive losses.

The Contributory Negligence Act allows courts to reduce a tortfeasor's liability by an "extent as the court thinks just and equitable having regard to the claimant's share in the responsibility for the damage". ${ }^{124}$ In limiting a tortfeasor's liability, courts measure the contributory negligence of a plaintiff at a fixed percentage, therefore, reducing a tortfeasor's liability by that percentage. ${ }^{125}$ In deciding whether to reduce a tortfeasor's liability, courts typically consider the "relative blameworthiness" of the plaintiff and tortfeasor and the "causative potency" of their respective acts. ${ }^{126}$ Courts assess blameworthiness against the degree to which the actor departs "from the standard of conduct exacted by law". ${ }^{127}$ Fault can range from "trivial inadvertence" through "to the grossest recklessness". 128

Under a system of proportionality liability concerning the liability of multiple tortfeasors, a tortfeasor is only liable for the percentage of a plaintiff's loss that a court determines is just, after considering that tortfeasor's "relative level of fault or comparative responsibility". ${ }^{129}$ This system, which has been widely adopted in Australia, ${ }^{130}$ protects tortfeasors from the imposition of liability that is disproportionate to their fault. ${ }^{131}$

However, there are essential differences between the Contributory Negligence Act and a system of proportional liability, and using a general liability limiting mechanism in negligence law.

First, reducing a tortfeasor's liability because of the fault of a plaintiff or another tortfeasor does not cut across the compensatory aim of negligence law. A plaintiff does need compensation for loss that they have caused, or for loss that will be compensated for by another tortfeasor. In contrast, if a

122 Invercargill City Council (SC), above n 33, at [115].

123 Rhee, above n 98, at 869.

124 Contributory Negligence Act 1947, s 3(1). See also, Fleming, above n 51, at 321; and Todd "Breach of Statutory Duty", above n 51, at 466.

125 Honoré, above n 62, at 93.

126 Invercargill City Council (CA), above n 24, at [136] per Miller J. For comparable positions in England and Australia see Stapley v Gypsum Mines Ltd [1953] AC 663 (HL) at 682; and Podrebersek v Australian Iron \& Steel Pty Ltd (1985) 59 ALJR 492 (HCA) at 494.

127 Fleming, above n 51, at 308.

128 At 308 .

129 Law Commission, above n 52, at [1.2].

130 Law Commission Liability of Multiple Defendants (NZLC R132, 2014) at [1.7].

131 At [Summary]. 
tortfeasor's liability were limited to achieve proportionality, the loss not compensated for by the tortfeasor would fall on the plaintiff, who was not at fault. Nevertheless, as discussed, a tortfeasor's interests should balance the compensatory aim of negligence law.

Secondly, in a general framework for limiting a tortfeasor's liability, the focus would solely be on the tortfeasor's fault. In contrast, the focus, when considering a claim of contributory negligence, is not only on the respective fault and blameworthiness of a tortfeasor and plaintiff. Courts are also required to assess causation; the extent to which the plaintiff factually contributed to the harm is important. However, Eagle $v$ Chambers demonstrates that fault is the overriding concern in a contributory negligence claim. ${ }^{132}$ In Eagle, the English Court of Appeal held that, while the tortfeasor's actions were "much more causatively potent than that of the claimant", the fault of the claimant justified a finding of 40 per cent contributory negligence. ${ }^{133}$ Therefore, Eagle suggests that the Contributory Negligence Act's framework for limiting liability, which is based on the equivalent legislation in the United Kingdom, ${ }^{134}$ is capable of being translated into a broader liability limiting mechanism, based on the relationship between a tortfeasor's fault and a plaintiff's loss.

\section{Reducing the Scope of a Tortfeasor's Duty of Care by a Percentage}

I propose that courts should be free to reduce the scope of a tortfeasor's duty of care to "such [an] extent as the courts thinks just and equitable", ${ }^{135}$ after weighing the degree of that tortfeasor's fault against the extent of the plaintiff's recoverable loss. Courts should be able to hold that a tortfeasor owed a duty of care to avoid only a percentage of the plaintiff's total loss. This method has two principal advantages over finding that the scope of a duty of care does not cover a particular head of loss.

First, this approach does not require distinguishable heads of loss, factually or conceptually. A tortfeasor's liability for a plaintiff's loss - even if the loss is singular and indistinguishable - can be reduced in sum. Secondly, this method is conceptually coherent because it allows differing levels of fault; it allows courts to ensure, where necessary, that a tortfeasor's liability is truly proportionate to their fault. For instance, under this approach, in the earlier example the inadvertently negligent tortfeasor could be liable for 80 per cent of the plaintiff's total loss, and the more blameworthy tortfeasor could be liable for 90 per cent of the same total of loss.

132 Eagle v Chambers [2003] EWCA Civ 1107, [2004] RTR 115 at [17]-[18]. See also Cempel v Harrison Hot Springs Hotel Ltd [1998] 6 WWR 233 (BCCA) at [19].

133 See for example James Goudkamp "Apportionment of damages for contributory negligence: a fixed or discretionary approach" (2015) 35 LS 621 at 624.

134 Law Reform (Contributory Negligence) Act 1945 (UK) 9 Geo VI c 28, s 1.

135 Contributory Negligence Act, s 3(1). 


\section{Judicial discretion}

Ultimately, as with contributory negligence claims, courts will not reduce a tortfeasor's liability in a "scientific or mathematical way". ${ }^{136}$ Instead, courts will make a value judgment, based on an assessment of the circumstances, on the appropriate balance between a plaintiff's compensatory interest and a tortfeasor's right to be free from undue burdens.

Scholars argue that judges are given too much discretion in determining the appropriate discount to a tortfeasor's liability in contributory negligence claims. ${ }^{137}$ Judges "can take account of whatever facts ... they feel are important (and ignore facts that they think are unimportant)". ${ }^{138}$ The same criticism could be levelled at this proposal. However, this article does not intend to give absolute freedom to judges in limiting a tortfeasor's liability.

First, judges are always under a duty to produce outcomes that are "roughly consistent with outcomes in other factually similar cases". ${ }^{139}$ This obligation prevents judges from indulging "fancy or mere whim", ${ }^{140}$ and mitigates the danger of inconsistency in outcomes for plaintiffs in negligence claims. A body of case law could develop around this proposal, from which judges could make comparisons in order to reach consistent and coherent decisions. Secondly, judicial discretion can be constrained by guidance. ${ }^{141}$ This article prescribes the factors courts must consider in assessing proportionality: the degree of the tortfeasor's fault and the extent of a plaintiff's loss. Ultimately, the benefits gained by enabling courts to reach "nuanced response[s] to the individual circumstances of each case" outweigh the detriment associated with judicial discretion. ${ }^{142}$ If this proposal fettered judicial discretion, this would curtail the capacity of courts to accommodate for differing levels of disproportionality. ${ }^{143}$

136 Goudkamp, above n 133, at 638. See also Glanville L Williams Joint Torts and Contributory Negligence: A Study of Concurrent Fault in Great Britain, Ireland and the Common-Law Dominions (Stevens \& Sons, London, 1951) at 390 .

137 See for example Goudkamp, above n 133.

138 At 624 .

139 At 625 .

140 HLA Hart "Discretion" (2013) 127 Harv L Rev 652 at 657.

141 Goudkamp, above n 133, at 641 .

142 At 637

143 See in the contributory negligence context Commonwealth of Australia Review of the Law of Negligence: Final Report (September 2002) at [8.16]. 


\section{THE FACTORS: FAULT AND LOSS}

\section{A Proportionality and Indeterminacy}

Before outlining how courts should measure a tortfeasor's fault and a plaintiff's loss, it is necessary to disentangle proportionality from the concept of indeterminacy. Proportionality is conceptually distinct from concerns about indeterminacy. ${ }^{144}$ The success of an argument that liability is indeterminate depends on whether liability is being imposed on a tortfeasor that is indeterminate (or, at least, vast) in amount, class and time, due to the number of individuals affected by a tortfeasor's conduct. ${ }^{145}$ Indeed, the Court of Appeal found that: ${ }^{146}$

... the implications of indeterminate liability of the scale in contemplation here are of such significance

that even the Crown ought not to be cast in the role of indemnifier.

Indeterminacy also looks to the potential for courts to set burdensome precedents. ${ }^{147}$ It was suggested that Mallon J's judgment did this by opening the floodgates for claims against regulators who make operational mistakes. ${ }^{148}$ Indeterminate liability is unconcerned with the degree of a tortfeasor's fault; in contrast, proportionality, in the context of negligence is law, centres on the degree of a tortfeasor's fault.

\section{B Addressing Fault and Loss in a Duty of Care Inquiry}

However, there is a practical problem in assessing a tortfeasor's fault and a plaintiff's loss in the proximity inquiry. A duty of care is the gateway to liability in negligence law. Therefore, courts generally undertake a duty analysis before considering a tortfeasor's fault and a plaintiff' loss. These matters are considered in the breach and remoteness inquiries, respectively. However, this article's proposal requires courts to pre-emptively consider these matters in a duty of care analysis, in order to decide whether to reduce the scope of a tortfeasor's duty of care. As noted by the Court of Appeal, analysing proportionality involves "introducing into the [duty] equation the nature and gravity of the assumed breach". ${ }^{149}$

Nevertheless, Mallon J's judgment and the wrongful conception and birth cases demonstrate that courts are capable of moving flexibly and interchangeably through the elements of negligence law; Mallon J, when assessing proportionality, considered MAF's fault and the orchardists' loss in her duty

144 The Grange, above n 17, at [159]. Compare Todd "Negligence: The Duty of Care", above n 18, at 161-162.

145 The Grange, above n 17, at [159].

146 Strathboss (CA), above n 8, at [260].

147 The Grange, above n 17, at [159].

148 Nikki Mandow "Opening the floodgates: what the PSA decision means for NZ" (18 December 2018) Newsroom <www.newsroom.co.nz>.

149 Strathboss (CA), above n 8, at [262]. 
of care analysis. ${ }^{150}$ Therefore, it is not impractical to require courts to address proportionality, and thus consider a tortfeasor's fault and a plaintiff's loss, while undertaking a duty of care analysis.

\section{The Degree of a Tortfeasor's Fault}

Tort law imposes liability for "socially unreasonable" conduct. ${ }^{151}$ Socially unreasonable conduct has degrees of increasing severity: negligence, recklessness and intentional infliction. Recklessness and intentional conduct, which require subjective blameworthiness, have a stigma that does not generally exist in relation to negligent conduct. ${ }^{152}$ In negligence law, an alleged tortfeasor will breach their duty of care if their conduct falls below the standard "demanded for the protection of others against unreasonable risk of harm", irrespective of their subjective mindset. ${ }^{153}$ An alleged tortfeasor's conduct will fall below this standard if a reasonable person would have acted differently in the circumstances. ${ }^{154}$

\section{Degrees of negligence in law}

Factually, there are indisputably degrees of negligence; in fact, there are "infinite shades", of objectively careless conduct. ${ }^{155}$ Negligence can involve "the slightest inattention" through to "the most reprehensible ... stupidity". ${ }^{156}$ However, scholars argue that there are no, and should not be, degrees of negligence in law. ${ }^{157}$ The breach requirement, which requires consideration of a tortfeasor's fault, is a "black-and-white concept". ${ }^{158}$ A tortfeasor has either breached their duty of care, and is at fault, or has not, and therefore, is not blameworthy. From this, scholars extrapolate that proportionality is irrelevant to negligence law; if there are no degrees of negligence in law, courts are

150 Strathboss (HC), above n 7, at [456]-[480].

151 Rhee, above n 98, at 870, as quoted in W Page Keeton (ed) Prosser and Keeton on the Law of Torts (5th ed, West Publishing, Minnesota, 1985) at 6.

152 James A Henderson Jr and Aaron D Twerski "Intent and Recklessness in Tort: The Practical Craft of Restating Law" (2001) 54 Vand L Rev 1133 at 1143; and Peter Cane "Mens Rea in Tort Law" (2000) 20 OJLS 533 at 533

153 Fleming, above n 51, at 117.

154 At 117

155 Shelden D Elliott "Degrees of Negligence" (1933) 6 S Cal L Rev 91 at 110

156 At 110

157 See for example Cane, above n 94, at 473; Handsley, above n 92, at 432; and Richard L Abel "Judges Write the Darndest Things: Judicial Mystification of Limitations on Tort Liability" (2002) 80 Tex L Rev 1547 at 1574.

158 Handsley, above n 92, at 433. 
incapable of assessing whether a particular award of damages is disproportionate to a tortfeasor's fault. ${ }^{159}$

However, the availability of exemplary damages in negligence law, which aim to punish tortfeasors who are "guilty of outrageous wrongdoing", ${ }^{160}$ demonstrates that there are degrees of negligence in law. ${ }^{161} \mathrm{~A}$ court will only award exemplary damages if it determines that a tortfeasor's fault is significant enough to warrant additional punishment. Similarly, the potential for proportionality to justify negating a duty of care illustrates that negligence has degrees. MAF's argument, which was unsuccessful for different reasons in both the High Court and Court of Appeal, was that the degree of its fault, when weighed against the burden of liability, was so minor that it did not owe the orchardists a duty of care. Moreover, the doctrine of contributory negligence illustrates that negligence has degrees; a plaintiff can only recover damages that are proportionate to the degree of fault attributable to the tortfeasor. ${ }^{162}$ Therefore, the issue is not whether there are degrees of negligence in law, but in how to measure those degrees, beyond trusting judicial instincts. ${ }^{163}$

\section{Measuring a tortfeasor's fault}

Currently, after a breach is established, the extent of a tortfeasor's fault is judged, not by their conduct, but primarily by the harm that they caused. ${ }^{164}$ This unduly favours a plaintiff's compensatory interest. While it has been suggested that negligent conduct that is not accompanied by subjective blameworthiness is not deserving of "moral censure", ${ }^{165}$ I argue that the level of a tortfeasor's objective carelessness can be used to determine the degree of a tortfeasor's fault. The blameworthiness of a tortfeasor who regularly plays with matches by a haystack, eventually causing property damage, is obviously greater than the fault of a tortfeasor who causes property damage by inadvertently dropping a matchstick.

159 Cane, above n 94, at 473.

160 Atkin, above n 92, at 1298.

161 Handsley, above n 92, at 432; Abel, above n 157, at 1574; and Peter Cane "Retribution, Proportionality, and Moral Luck in Tort Law" in Peter Cane and Jane Stapleton (eds) The Law of Obligations: Essays in Celebration of John Fleming (Clarendon Press, Oxford, 1998) 141 at 171.

162 Elliott, above n 155, at 135 .

163 Williams, above n 136, at 158.

164 Cane, above n 94, at 473; and Compensation for Personal Injury in New Zealand, above n 1, at [85].

165 Compensation for Personal Injury in New Zealand, above n 1, at [88]. See also Heidi M Hurd "Finding No Fault with Negligence" in John Oberdiek (ed) Philosophical Foundations of the Law of Torts (Oxford University Press, Oxford, 2014) 387 at 387. 
Scholars who accept that there are degrees of negligence in law tend to divide negligence into three degrees (see Figure 1). ${ }^{166}$ Slight negligence consists of the "failure to use great care", ordinary negligence involves the "failure to use ordinary care" and gross negligence is "the failure to use even slight care". ${ }^{167}$ Gross negligence, as this article defines it, does not require a subjective component; rather, it differs from simple and ordinary negligence in degree. ${ }^{168} \mathrm{~A}$ tortfeasor's subjective mindset is not relevant to measuring the degree of the fault. ${ }^{169}$

Figure 1. ${ }^{170}$

DiaGram No. 3

NEGLIGENCE

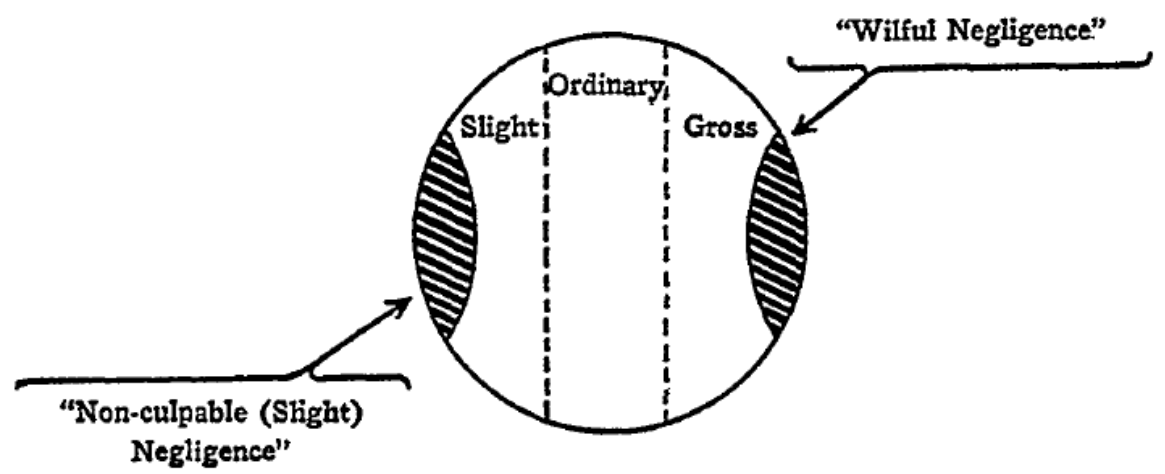

I propose that courts should measure the degree of a tortfeasor's fault by placing their conduct on a scale between slight negligence (which meets the breach threshold) through to gross negligence. The more advanced a tortfeasor's negligence is, the more blameworthy that tortfeasor is, ${ }^{171}$ and the less likely it is that the mechanism proposed in this article will be engaged. Indeed, if a court determines that a tortfeasor's conduct leans towards gross negligence, that court should be prohibited from limiting that tortfeasor's liability, as to do so would not achieve proportionality. This article only

166 See Elliott, above n 155, at 95 for Figure 1.

167 Keeton, above n 151, at 210 .

168 At 212

169 See for example, Cane, above n 152, at 556.

170 See Elliott, above n 155, at 95 for Figure 1.

171 Blaine LeCesne "Crude Decisions: Re-Examining Degrees of Negligence in the Context of the BP Oil Spill" [2012] Mich St L Rev 103 at 136. 
aims to allow courts to produce fairer outcomes for tortfeasors who cause significant loss through mid-to-low-level negligence.

However, articulating negligence into three degrees is of limited utility; it "merely ... break[s] up one broad generality into three". ${ }^{172}$ Therefore, this article proposes that a series of tiered factors should be used to determine where on the negligence scale a tortfeasor's conduct falls. ${ }^{173}$ I outline, without intending to be exhaustive, certain factors that courts should consider. The weight and balance given to these factors will depend on a court's view of the relevant evidence. This will enable courts to adjust to the varied circumstances that arise in negligence claims. ${ }^{174}$

The sole tier-one factor proposed is the degree of risk involved in the negligent act or omission. ${ }^{175}$ This requires courts to objectively consider, in the tortfeasor's shoes, how likely the conduct was to cause harm and the magnitude of harm that could have been foreseen. ${ }^{176}$ This inquiry should be made in "in light of the overall activity setting", because certain activities, such as playing with matches by a haystack, inherently carry a high likelihood for significant harm to occur. ${ }^{177}$ This factor should bear the most "probative weight": ${ }^{178}$ conduct that was unlikely to cause harm, especially significant harm, should be placed towards the lower end of the negligence scale.

Two tier-two factors are proposed. The first is whether the tortfeasor was performing a public function. If the tortfeasor was protecting the public and the public was reliant on the tortfeasor for that protection, this indicates that the tortfeasor is blameworthy. However, a subset of this factor is whether an award of damages would ultimately be "borne by the public through taxes". ${ }^{179}$ If the New Zealand public is to be "the insurer or guarantor of losses", ${ }^{180}$ this should be a strong countervailing consideration.

172 Elliott, above n 155, at 142

173 LeCesne, above n 171, outlined a similar proposal.

174 At 106 and 134.

175 At 151. See also Mobil Oil Corp v Ellender 968 SW 2d 917 (Tex 1998) at 921, as cited in Patrick H Martin "The BP Spill and the Meaning of 'Gross Negligence or Willful Misconduct'" (2011) 71 La L Rev 957 at 996.

176 Martin, above n 175, at 996.

177 LeCesne, above n 171, at 151.

178 At 153 .

179 Strathboss (HC), above n 7, at [478].

180 At [478] 
The next tier-two factor is whether the tortfeasor's conduct was consistent with past practice. ${ }^{181}$ For example, repeated "tolerance for safety lapses" involves a high degree of blameworthiness. ${ }^{182}$ In contrast, if a tortfeasor's negligence was an isolated event, this indicates a lower level of fault. The last factor proposed is whether there are any "exigent circumstances". ${ }^{183}$ This factor is intended to operate as a "justification mechanism", allowing tortfeasors to explain whether any extraneous circumstances compelled them to act as they did. ${ }^{184}$ If this is the case, a tortfeasor may be less blameworthy than it appeared at first instance.

\section{The Extent of a Plaintiff's Loss}

A tortfeasor can cause significant loss in two ways: an individual may suffer extensive loss, or numerous individuals may suffer smaller losses that cumulatively total significant loss. This article addresses both scenarios, assuming that, if multiple individuals suffer small losses, an action is taken collectively under r 4.24 of the High Court Rules 2016, as in Strathboss. ${ }^{185}$

The extent of a plaintiff's loss in a negligence claim is a question of fact, depending on evidence and proof. In general, it will be easier for courts to establish the extent of a plaintiff's loss than the tortfeasor's degree of fault.

The filters of causation and remoteness can limit a plaintiff's damages. ${ }^{186}$ Moreover, certain heads of loss are unrecoverable in negligence law, such as relational economic loss. ${ }^{187}$ Therefore, when comparing a plaintiff's loss with a tortfeasor's fault, courts should only weigh the loss that is recoverable. Unrecoverable loss has no bearing on whether a tortfeasor's liability is disproportionate.

This article aims to constrain the compensatory objective of negligence law. Courts should not consider non-compensatory damages when measuring a plaintiff's loss. Courts should also consider a plaintiff's recoverable loss in sum, even if there are multiple heads of recoverable loss. For example, if the proposed mechanism were to be used in a stage two hearing in Strathboss, the extent of recoverable property damage and consequential loss would be considered cumulatively. This is because the recoverability of a particular head of loss will not generally be why a tortfeasor's liability is disproportionate to their fault. Moreover, while the recoverability of certain heads of loss are more

181 LeCesne, above n 171, at 154.

182 At 154

183 At 158

184 At 158

185 Strathboss Kiwifruit Ltd v Attorney-General [2015] NZHC 1596

186 Todd "Causation and Remoteness of Damage", above n 55, at 1068 and 1104-1105. See also Overseas Tankship (UK) Ltd v Morts Dock \& Engineering Co Ltd, above n 59, at 426.

187 Todd "Negligence: The Duty of Care", above n 18, at 259. 
controversial than others, ${ }^{188}$ all recoverable loss should be treated equally when assessing a proportionality claim. This is because, once a head of loss is deemed to be recoverable, it has the same effect on the proportionality between a tortfeasor's fault and their liability as a less controversial head of loss, such as property damage.

\section{CONCLUSION}

Negligence law in New Zealand does not reflect "fundamental fairness", 189 as, to borrow from the language of the criminal law, the punishment does not fit the crime. ${ }^{190}$ Moral luck determines whether "inattention or slowness to react" results in crushing legal liability or no liability at all. ${ }^{191}$ The extent of a tortfeasor's liability, with the exceptions of contributory negligence and exemplary damages, is determined without considering the degree of their fault. ${ }^{192}$

The prompt for this article was Mallon J's unclear analysis in Strathboss of MAF's claim that imposing liability for the Psa3 incursion was disproportionate to its fault. However, the critical issue is with the inflexible framework which case law dictated Mallon J, and the Court of Appeal, use. Courts in New Zealand have historically only used the concept of proportionality in negligence law as a factor contributing to the negation of a duty of care. As Strathboss illustrates, this approach is flawed because, by not allowing a tortfeasor's liability to be limited, it cannot achieve true proportionality. Moreover, negligence law's liability limiting mechanisms will not always operate to ensure there is proportionality between a tortfeasor's fault and a plaintiff's loss.

Proportionality, in the context of negligence law, requires that the liability imposed on a tortfeasor be fair both to the harmed party in terms of compensation, and to that tortfeasor. Negligence law should not unduly burden tortfeasors. ${ }^{193}$ Internationally, courts in the wrongful conception and birth cases have struck this balance in allowing parents to claim for loss associated with pregnancy and childbirth, but not for upbringing costs or lost earnings. However, the liability limiting mechanisms used by the courts in these cases are fact-specific. This article develops on these cases, proposing that courts should be able to reduce the scope of a tortfeasor's duty of care to "such [an] extent as the court

188 Michael A Jones "Negligence" in Clerk and Lindsell on Torts (21st ed, Thomson Reuters, London, 2014) 439 at n 58; and Woolcock Street Investments Pty Ltd v CDG Pty Ltd [2004] HCA 16, (2004) 216 CLR 515 at [98]-[99].

189 Rhee, above n 98, at 869

190 Robert L Rabin "Tort Recovery for Negligently Inflicted Economic Loss: A Reassessment" (1985) 37 Stan L Rev 1513 at 1535.

191 Abel, above n 157, at 1574. See also Rhee, above n 98, at 869; Honoré, above n 62, at 89; and Geistfeld, above n 94, at 610 .

192 Goldberg and Zipuersky, above n 90, at 1140 .

193 Hnatt, above n 95, at 1193. 
thinks just and equitable". ${ }^{194}$ In deciding whether this is necessary, courts must first consider the degree of a tortfeasor's fault and then weigh this fault against the plaintiff's recoverable loss. Ultimately, considering issues of proportionality in a more nuanced framework will ensure that the law of negligence delivers just results. 
